\title{
PENGARUH PRIVASI, KEAMANAN, KEPERCAYAAN DAN PENGALAMAN TERHADAP PENGGUNAAN FINTECH DI KALANGAN MASYARAKAT KABUPATEN TANGERANG BANTEN
}

\author{
Dr. Gatot Efrianto, S.H.,M.H \\ gefrianto212@gmail.com \\ Program Studi Ilmu Hukum, Universitas Bhayangkara Jakarta Raya \\ Nia Tresnawaty, S.E.,M.Ak \\ niatresna@yahoo.com \\ Program Studi Akuntansi, Universitas Satya Negara Indonesia
}

\begin{abstract}
ABSTRAK
Tujuan penelitian ini adalah untuk mengetahui pengaruh privasi, keamanan, kepercayaan dan pengalaman terhadap penggunaan fintech di kalangan mayarkat Kabupaten Tangerang, Banten. Populasi dalam penelitian ini adalah masyarakat yang berdomisili di wilayah Kecamatan Tigaraksa, Kabupaten Tangerang Banten. Sampel yang digunakan 450 responden dari 167.487 jumlah penduduk di Kecamatan Tigaraksa berdasarkan data statistik SIGA DP3A Kabupaten Tangerang tahun 2020. Data penelitian ini adalah data primer yang diperoleh melalui penyebaran kuesioner. Teknik pengambilan sampel menggunakan metode sampling random. Hasil penelitian ini menunjukkan bahwa pengaruh privasi dan keamanan tidak berpengaruh, sedangkan kepercayaan dan pengalaman berpengaruh positif dan signifikan terhadap penggunaan fintech di kalangan masyarakat Kabupaten Tangerang Banten. Dan pengaruh privasi, keamanan, kepercayaan dan pengalaman secara simultan berpengaruh positif dan signifikan terhadap penggunaan fintech di kalangan masyarakat Kabupaten Tangerang, Banten sebesar 53,8\%. Sedangkan sebagiannya sebesar $46,2 \%$ dijelaskan oleh variabel lain yang tidak termasuk dalam model penelitian ini.
\end{abstract}

Kata Kunci: Privasi, Keamanan, Kepercayaan dan Pengalaman, Penggunaan Fintech 


\section{PENDAHULUAN}

Di era kemajuan jaman yang semakin meningkat Indonesia merupakan negara yang selangkah lebih maju khususnya di wilayah Kabupaten Tangerang dengan diperkenalkan serba digital baik di lingkungan maupun di luar lingkungan pekerjaan. Kata Fintech berasal dari kata financial dan technology yang memiliki arti sebuah innovasi dalam lembaga jasa keuangan atau finansial yang memberikan sentuhan atau kemudahan di bidang teknologi modern yang dapat membantu untuk memaksimalkan dalam penggunaan teknologi untuk mengubah, mempertajam atau mempercepat berbagai aspek pelayanan keuangan yang nantinya dipergunakan untuk metode pembayaran hingga mentransfer dana, pengumpulan dana, pinjaman dana, pengelolaan aset keuangan dan lain sebagainya.

Fintech merupakan terobosan dan innovasi baru di dalam dunia perbankan hal ini pula yang salah satu dapat membantu menumbuhkan dan meningkatkan taraf hidup, Indonesia melihat ini suatu terobosan yang baik maka melalui dukungan pemerintah melalui Bank Indonesia membuat suatu aturan sebagai pondasi landasan hukum yaitu :

1. Surat Edaran Bank Indonesia No.18/22/DKSP tentang Penyelenggaraan Lembaga

Keuangan Digital.

2. Peraturan Bank Indonesia No.18/40/PBI/2016 tentang Penyelenggaraan Pemrosesan

Transaksi Pembayaran.

3. Peraturan Bank Indonesia No.18/17/PBI/2016 tentang Uang Elektronik.

Dengan telah dibuatkan dan ditetapkan aturan-aturan hukum yang dapat menjadi dasar hukum dalam melakukan transaksi keuangan secara aman dengan menggunakan innovasi baru ini.

Tabel 1

Penggunaan E-Commerce Dunia Jan 2019-Jan 2020

\begin{tabular}{|r|l|r|}
\hline No & Negara & Persentase \\
\hline 1 & Indonesia & $88 \%$ \\
\hline 2 & Thailand & $82 \%$ \\
\hline 3 & Poland & $82 \%$ \\
\hline 4 & Germany & $82 \%$ \\
\hline 5 & Malaysia & $82 \%$ \\
\hline 6 & U.k & $81 \%$ \\
\hline 7 & South Korea & $80 \%$ \\
\hline
\end{tabular}

Sumber: Wearesocial.com

Indonesia dalam laporan digital We Are Social adalah negara dengan adopsi (penggunaan) e-commerce terbesar di dunia. Angkanya mencapai $88 \%$ dari seluruh pengguna internet yang ada di Indonesia. Meningkatnya popularitas transaksi secara online (e-commerce) di Indonesia mengubah gaya hidup masyarakat, termasuk dalam sistem pembayaran yang telah menggunakan sistem pembayaran non-tunai dalam transaksi e-commerce.

Jurnal Ilmiah Akuntansi dan Ekonomi Volume. 6 Nomor. 1, Februari 2021 Hal. 54 


\section{Gambar 1}

penggunaan jenis pembayaran online/fintech di e-commerce tahun 2020

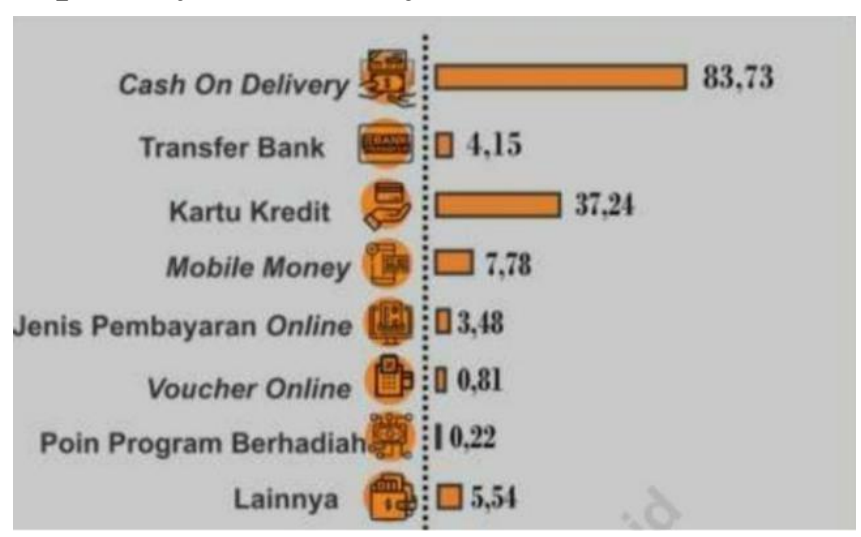

Sumber:https://www.bps.go.id/

Berdasarkan data dari badan statistik 2020 penggunaan jenis pembayaran online/fintech masih sangat rendah yaitu hanya $11.26 \%$ ( mobile money $7,78 \%$ dan jenis pembayaran online 3,48\%) dari seluruh transaksi yang ada. Sebagian besar pembayaran e-commers masih menggunakan cash on delivery.

Sementara berdasarkan karakteristik dari penyelenggara dan pengguna sesuai data OJK per 31 Desember 2020 adalah sebagai berikut :

\section{Gb.2}

Penyelenggara Financial Technology

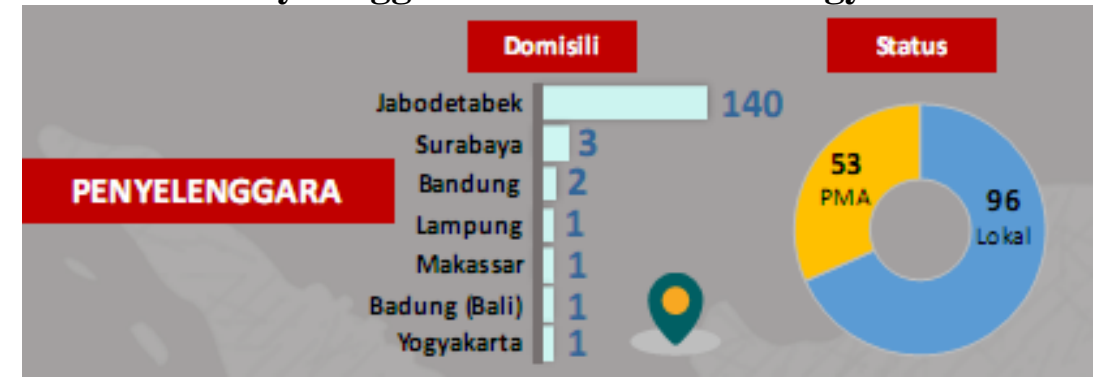

Sumber : Data OJK per 31 Desember 2020

Berdasarkan data statistik di atas, maka dapat dilihat bahwa dari 149 penyelenggara fintech yang paling banyak penyelenggaranya adalah di wilayah Jabodetabek sebanyak 140 perusahaan, dengan status perusahaan lokal sebanyak 96 perusahaan dan PMA sebanyak 53 perusahaan.

Berdasarakan data statistik terkait usia dan pengguna Fintech dapat dilihat bahwa yang terbanyak adalah dalam rentang usia 19 - 34 tahun dan jika dilhat berdasarkan penggunanya adalah yang paling banyak adalah perorangan dengan jenis kelamin laki-laki yaitu sebesar 52,7\% seperti dapat dilihat dalam gambar berikut ini : 
Gb.3

Pengguna Financial Technology

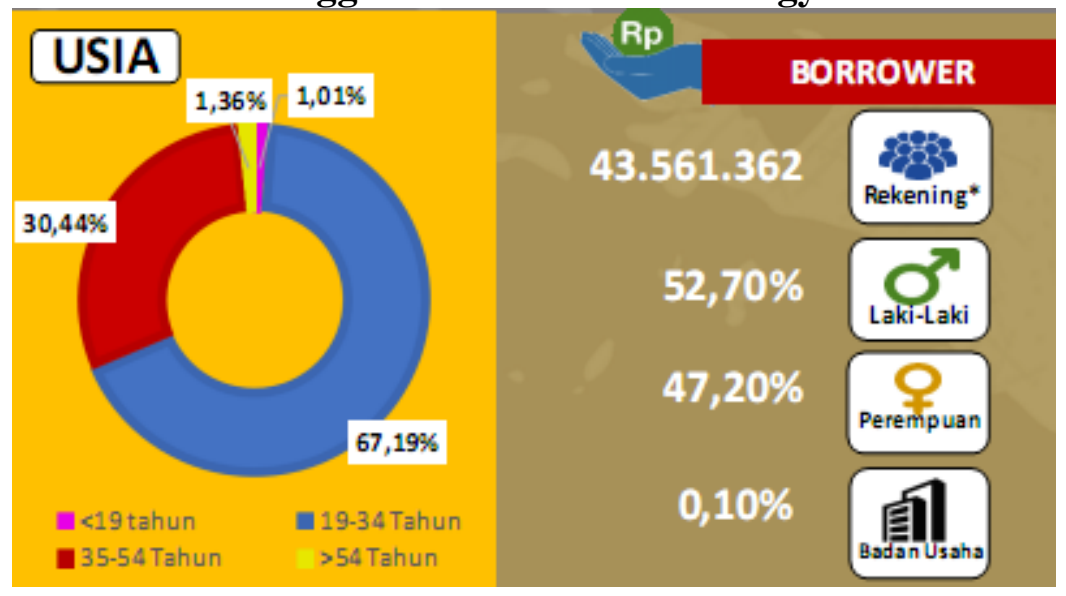

Sumber : Data OJK per 31 Desember 2020

Gb.4

Peminjam Aktif berdasarkan wilayah

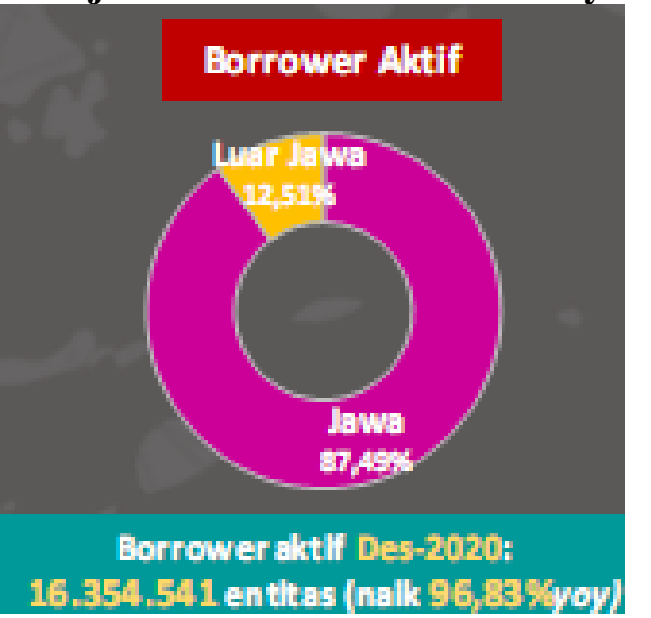

Sumber : Data OJK per 31 Desember 2020

Berdasarkan data statistik bahwa borower aktif berada di wilayah pulau jawa sebesar $87,49 \%$.

Hal tersebut membuka peluang layanan keuangan berbasiskan teknologi atau financial technology (fintech) membesarkan jangkauan usaha dan pasarnya. Menurut Bank Indonesia, financial technologi merupakan hasil gabungan antara jasa keuangan dengan teknologi yang akhirnya mengubah model bisnis dari konvensional menjadi online, yang awalnya sistem pembayaran dilakukan dengan tatap-muka dan membawa sejumlah uang kas, kini dapat dilakukan dengan transaksi jarak jauh dan dapat dilakukan dalam hitungan detik saja. Theory Acceptance Model (TAM) diadopsi dari model The Theory of Reasoned Action (TRA), yaitu teori tindakan yang dikembangkan oleh Fishbein dan Ajzen (1975),

Jurnal Ilmiah Akuntansi dan Ekonomi Volume. 6 Nomor. 1, Februari 2021 Hal. 56 
dengan satu premis bahwa reaksi dan persepsi seseorang terhadap sesuatu hal, akan menentukan sikap dan perilaku orang tersebut. Teori ini membuat model perilaku seseorang sebagai suatu fungsi dari tujuan perilaku. Tujuan perilaku ditentukan oleh sikap atas perilaku tersebut. Model TAM yang dikembangkan dari teori psikologis menjelaskan perilaku pengguna komputer, yaitu kepercayaan (believe), dan pengalaman.

Salah satu faktor yang mempengaruhi seseorang menggunakan financial teknologi adalah privasi. Privasi meliputi data yang membahas regulasi proteksi terhadap privasi. Selain Privasi, faktor keamanan juga menjadi faktor yang mempengaruhi seseorang dalam menggunakan fintech. Kegiatan dalam E-Commerce disamping memberikan keuntungan dalam bertransaksi secara online, disisi lain mengandung beberapa resiko diantaranya adalah, gangguan website yang diakibatkanoleh para hacker. Selain privasi dan keamanan, faktor yang sangat penting untuk mempengaruhi minat seseorang dalam menggunakan fintech adalah faktor kepercayaan. Kepercayaan memiliki indikator yang dapat dijadikan sebagai ukuran

untuk mengukur minat berperilaku dalam menggunakan suatu sistem informasi.. Menurut Chuang (2016) mengidentifikasikan tiga indikator dari kepercayaan (trust), yaitu Keyakinan pada layanan teknologi informasi yang disediakan oleh sebuah perusahaan layanan teknologi informasi, adanya kualitas transaksi sebuah layanan teknologi informasi, dan keamanan sebuah layanan teknologi dimana informasi dapat dilihat pada kerahasiaan data dan kegiatan yang berlangsung selama mengoperasikan layanan tersebut. Dan selanjutnya pengalaman, pengalaman yang memuaskan akan mengakibatkan menggunakan untuk melakukan ulang di masa yang kan datang.

Menurut Asosiasi Financial Technology Indonesia (AFTECH), target terbesar pasar fintech di Indonesia adalah generasi millenial kelas menengah yaitu penduduk yang lahir antara tahun 1980an sampai 2000an. Generasi ini muncul dengan ditandai oleh peningkatan penggunaan dan keakraban dengan media dan teknologi digital. Oleh karena itu penelitian ini dilakukan oleh kalangan Masyarakat. Berdasarkan latar belakang yang telah diuraikan diatas, maka judul dalam penelitian ini adalah, "Pengaruh Privasi, Keamanan, Kepercayaan dan Pengalaman Terhadap Penggunaan Fintech di Kalangan Masyarakat Kabupaten Tangerang,Banten"

\section{LANDASAN TEORI}

\section{TAM (Technology Acceptance Model)}

Menurut Davis, TAM adalah sebuah teori yang dirancang untuk menjelaskan bagaimana pengguna mengerti dan menggunakan sebuah teknologi informasi. TAM menggunakan TRA dari Fishbein dan Ajzen yang digunakan untuk melihat bagaimana tingkat adopsi responden dalam menerima teknologi informasi (Jogiyanto:2007). Model penelitian TAM dikembangkan dari berbagai perspektif teori. Pada awalnya teori inovasi difusi yang merupakan teori yang paling mendominasi penerimaan dan berbagai model

Jurnal Ilmiah Akuntansi dan Ekonomi Volume. 6 Nomor. 1, Februari 2021 Hal. 57 
penerimaan teknologi (Jogiyanto:2007). TAM memiliki tujuan untuk menjelaskan dan memprediksikan penerimaan pemakai terhadap suatu teknologi. TAM adalah pengembangan TRA dan diyakini mampu meramalkan penerimaan pemakai terhadap teknologi berdasarkan dampak dari dua faktor, yaitu perspektif kemanfaatan (perceived usefulness) dan perspektif kemudahan pemakaian (perceived ease of use) (Davis, 1989).

Menurut Shim \& Drake, (1990) dalam lingkungan belanja online, pengalaman pembelian online sebelumnya mengarah pada pengurangan ketidakpastian dan akhirnya menyebabkan peningkatan dalam niat beli konsumen. Jika pengalaman pembelian online sebelumnya memberikan hasil yang memuaskan, hal ini akan mengakibatkan pelanggan untuk terus berbelanja melalui internet di masa depan (Ling et al,2010).

\section{Financial Teknologi}

Fintech merupakan singkatan dari kata Financial Technology, yang dapat diartikan dalam bahasa Indonesia menjadi teknologi keuangan. Secara sederhana, Fintech dapat diartikan sebagai pemanfaatan perkembangan teknologi informasi untuk meningkatkan layanan di industri keuangan.

Teknologi Finansial menurut peraturan Bank Indonesia Nomor 19/12/PBI/2017 adalah penggunaan teknologi sistem keuangan yang menghasilkan produk, layanan, teknologi, dan/atau model bisnis baru serta dapat berdampak pada stabilitas moneter, stabilitas sistem keuangan, efesiensi, kelancaran, kemananan dan keandalan sistem pembayaran. Penyelenggara teknologi finansial yakni meliputi sistem pembayaran, pendukung pasar, manajemen investasi dan manajemen resiko, pinjaman, pembiayaan dan penyedia modal, dan jasa finansial lainnya.

Di Indonesia, fintech sudah didukung oleh BI dan OJK pada penggunaannya. OJK telah membuat Peraturan Otoritas Jasa Keuangan (POJK) Nomor 77/POJK.01/2016 tentang Layanan Pinjam Meminjam Uang Berbasis Teknologi Informasi pada akhir tahun 2016 . Hal ini mengatur industri keuangan yang menjual dan menggunakan fintech di Indonesia. Saat ini di Indonesia, berdasarkan jenis penggunanya, dipisahkan menjadi bank dan nonbank. Istilah fintech sendiri lebih populer kepada perusahaan rintisan non-bank yang menyedikan layanan keuangan berbasis teknologi.

Pengaturan dan pengawasan OJK terhadap bisnis Fintech juga diatur dalam POJK No. 13 /POJK.02/2018 tentang Inovasi Keuangan Digital di Sektor Jasa Keuangan, tujuannya untuk penyelenggaraan Inovasi Keuangan Digital (IKD) secara bertanggung jawab. Pengaturan IKD dilakukan dengan tujuan untuk mendukung pengembangan IKD yang bertanggung jawab, mendukung pemantauan IKD yang efektif, dan mendorong sinergi di dalam ekosistem digital jasa keuangan sebagaimana diatur dalam Pasal 2 ayat (1) dan (2) tentang tujuan IKD.

\section{Privasi}

Menurut Kamus Besar Bahasa Indonesia Privasi adalah kebebasan dan keleluasan pribadi. Privasi menurut UU Teknologi Informasi ayat 19 adalah hak individu untuk mengendalikan penggunaan informasi tentang identitas pribadi baik oleh dirinya sendiri

Jurnal Ilmiah Akuntansi dan Ekonomi Volume. 6 Nomor. 1, Februari 2021 Hal. 58 
atau oleh pihak lainnya. Ketentuan privasi sudah di atur dalam UUD 1945 Pasal 28 G ayat (1) yaitu setiap orang berhak atas perlindungan diri pribadi (privasi), keluarga, kehormatan, martabat, dan harta bendanya (termasuk data-data pribadi).

Perlindungan privasi dikembangkan untuk mengatur perilaku orang lain yang dapat mengganggu dengan berbagai cara pada kehidupan seseorang. Privasi dalam konteks ini dapat dipahami secara umum, membatasi kemampuan orang lain untuk mendapatkan, menyebarkan, atau menggunakan informasi tentang data diri (Anggara 2015).

Privasi dalam bertransaksi online sangatlah penting. Menurut Otoritas Jasa Keuangan (2016), Resiko yang dialami oleh pengguna Fintech dalam bertransaksi online. Sehingga diperlukan adanya strategi untuk melindungi konsumen dan kepentingan nasional. Strategi untuk melindungi konsumen adalah sebagai berikut:

1. Perlindungan dana pengguna Potensi kehilangan maupun penurunan kemampuan finansial, baik yang diakibatkan oleh penyalahgunaan, penipuan, maupun force majeur dari kegiatan Fintech.

2. Pelindungan data pengguna Isu privasi pengguna fintech yang rawan terhadap penyalahgunaan data baik yang disengaja maupun tidak sengaja .

\section{Kemananan}

Keamanan adalah suatu keadaan dimana tidak ada sesuatu yang menggelisahkan (Poerwadarminta, 2006 : 30). Keamanan komputer adalah usaha untuk menghindari peristiwa yang tidak diinginkan seperti tidak adanya kerahasiaan dan integritas data. Sistem keamanan mencoba untuk mencegah penipuan dan penyalahgunaan lain sistem komputer, sistem ini bertindak sebagai pelindung dan juga merupakan kepentingan sah dari berbagai konstituensi sistem tersebut .

Fintech ini telah diproteksi dengan sistem keamanan SSL 256 bit dan three layer security (password, secure PIN, dan kode OTP). Sistem keamanan lapis tiga ini ternyata selangkah lebih maju dari dunia perbankan yang hanya menggunakan 2 faktor Authentication (2FA) yaitu level password dan level OTP. Fintech ini disokong 3 Faktor Authentication (3FA) yaitu level password, randomized numerical PIN dan OTP (One Time Password). Level password terdiri atas kombinasi (minimum) 8 digit angka, huruf dan spesial karakter. Level randomized numerical PIN adalah sistem pengacakan 10 digit nomor yang hanya bisa dipilih melalui klik atau layar sentuh hasil kreasi team IT IndoPremier. Lapis keamanan ini mampu mengantisipasi malware seperti key-logger. Sementara itu, level OTP sendiri berupa password acak dan unik yang dikirimkan melalui SMS kepada pengguna dengan masa berlaku 3 menit. Dengan sistem keamanan lapis tiga ini data pribadi nasabah aman dan terlindungi dari ancaman hacker saat menggunakan fintech.Potensi kejahatan berupa penipuan, pembajakan kartu kredit (carding) dan sejenisnya sangatlah besar apabila sistem keamanan (security) infrastruktur rendah. Maka dari itu dengan adanya penerapan Fintech pembayaran akan dirasa lebih aman.

Menurut Ide Ismaili (2015) Persyaratan keamanan e-payment dalam transaksi online yaitu :

Jurnal Ilmiah Akuntansi dan Ekonomi Volume. 6 Nomor. 1, Februari 2021 Hal. 59 
1. Kerahasiaan ( Confidentiality)

Kerahasiaan disini dimaksudkan adalah suatu data atau paket data tidak diperbolehkan dibaca atau diketahui oleh orang lain atau pihak lain yang tidak berkepentingan.

2. Otensitas ( Authenticity)

Otentisitas merupakan proses verifikasi terhadap identitas pengirim data

3. Integritas ( Integrity)

Keutuhan data atau paket data yang dikirim kan oleh pengirim dan penerima data atau paket data yang diterimanya benar-benar utuh dan tidak dimanipulasi.

4. Tidak Dapat Disangkal ( non repudiation )

Setiap pengiriman data atau paket data, pengirim tidak bisa menyangkal bahwa tidak pernah mengirim data atau paket data tersebut.

\section{Kepercayaan}

Kepercayaan adalah ciri utama dari sebagian besar interaksi ekonomi dan sosial yang menyebabkan ketidakpastian. Secara praktis, semua interaksi membutuhkan elemen kepercayaan terutama yang dilakukan di lingkungan teknologi informasi yang tidak pasti. Kepercayaan selalu menjadi elemen penting dalam memengaruhi perilaku konsumen dan telah terbukti sangat penting dalam lingkungan yang tidak pasti, seperti pada konteks Financial Technology yang berbasis Internet.

Indikator kepercayaan menurut Chuang, et.al. (2016) yaitu :

1. Keyakinan pada Layanan

Dimensi ini berkaitan dengan kepercayaan seorang individu terhadap layanan teknologi informasi yang disediakan oleh sebuah perusahaan layanan teknologi informasi. Jika seorang individu percaya pada perusahaan layanan teknologi informasi yang menyediakan layanan tersebut maka keyakinan individu dalam menggunakan layanan teknologi informasi tersebut menjadi semakin besar.

\section{Persepsi Kualitas Layanan}

Dimensi ini berkaitan dengan kepercayaan seorang individu terhadap kualitas sebuah layanan teknologi informasi. Sebuah layanan teknologi informasi menyediakan kualitas pengoperasian layanan yang berbeda. Jika seorang individu merasa terpenuhi atas kualitas transaksi sebuah layanan teknologi informasi maka kepercayaan seorang individu dalam menggunakan layanan teknologi informasi tersebut menjadi semakin besar.

3. Persepsi Keamanan Layanan

Dimensi ini berkaitan dengan kepercayaan seorang individu terhadap keamanan sebuah layanan teknologi informasi. Keamanan sebuah layanan teknologi informasi dapat dilihat pada kerahasiaan data dan kegiatan yang berlangsung selama mengoperasikan layanan tersebut. Jika seorang individu merasa terpenuhi atas keamanan 
transaksi sebuah layanan teknologi informasi maka kepercayaan seorang individu dalam menggunakan layanan teknologi informasi tersebut menjadi semakin besar.

\section{Pengalaman}

Pengalaman adalah sesuatu yang sudah dirasai, diketahui, dan dikerjakan (Poerwadarminta, 2006:22). Pengalaman bisa menjadikan orang lebih bersikap hati-hati dan bisa mempertimbangkan segala sesuatu secara tenang dan matang. Pengguna internet yang berpengalaman, waktu yang mereka habiskan untuk online lebih banyak karena keahlian yang mereka peroleh melalui pengalaman, seharusnya yakin bahwa internet lebih bisa dipercaya dari pada mereka yang kurang berpengalaman. Intinya adalah bahwa kepercayaan muncul dengan tingkat pengetahuan tertentu, dimana pengetahuan diperoleh dari pengalaman.

Assauri (2015) menegaskan bahwa ketika seseorang memiliki pengetahuan yang kurang sebelumnya pada masalah yang dihadapi, pilihan perilaku yang akan dilakukan sebagian besar bergantung pada nilai harapan.

Selain itu hal yang perlu diperhatikan oleh para penyelenggara fintech ialah kemudahaan atau kepraktisan dalam menggunakan layanan, sehingga masyarakat yang kurang memahami teknologi dapat menggunakannya dengan mudah sehingga diharapkan kedepannya akan mendapatkan pengalaman yag memuaskan. Pengalaman yang memuaskan akan mengakibatkan niat untuk melakukan ulang di masa yang kan datang.

\section{Penggunaan Fintech}

Dalam Kamus Besar Bahasa Indonesia penggunaan diartikan sebagai proses, cara perbuatan memakai sesuatu, pemakaian. (KBBI, 2002:852). Penggunaan sebagai aktifitas memakai sesuatu atau membeli sesuatu berupa barang dan jasa. Pembeli danpemakai yang dapat disebut pula sebagai komsumen barang dan jasa. Dalam penelitian ini penggunaan adalah penggunaan financial technology (Fintech) untuk jasa pembayaran online dalam bertransaksi. Tingkat penggunaan sebuah teknologi informasi pada seseorang dapat diprediksi dari sikap perhatiannya terhadap teknologi tersebut, misalnya Rasa ingin menggunakan, selalu menggunakan dan berlanjut menggunakan di masa yang akan datang.

\section{METODE PENELITIAN}

Penilitian ini menggunakan pendekatan kuantitatif. Desain penelitian yang digunakan adalah Penelitian Kausal (Causal Research) yang merupakan metode penelitian untuk mengetahu hubungan satu atau lebih variable bebas (independent variable) terhadap variable terikat (dependent variable). Variabel bebas (Independent variable) dalam penelitian ini adalah privasi, keamanan, kepercayaan dan pengalaman. Variabel terikat (dependent variable) dalam penelitian ini adalah penggunaan fintech di kalangan masyarakat. 
Teknik pengumpulan data dilakukan dengan metode angket, yaitu teknik pengumpulan data dengan cara menyebarkan instrument (kuisioner) yang berisi daftar pertanyaan kepada responden. Jenis data yang digunakan adalah data primer dengan teknik sampling yang digunakan adalah pengambilan sampel menggunakan sample random sampling dengan menggunakan rumus solvin. Sample dalam penelitian Berdasarkan rumus slovin yaitu sebanyak 399 responden dari 167.487 jumlah penduduk Kecamatan Tigaraksa, Kabupaten Tangerang Banten. Sample yang peneliti gunakan adalah 450. Jumlah tersebut adalah diatas nilai slovin karena untuk mengantisipasi adanya kuesioner yang tidak dapat diolah.

\begin{tabular}{|l|l}
$\mathrm{n}=\frac{N}{1+N e^{2}}$ & $\mathrm{n}=\frac{167.487}{1+\left(167.487 \times(0,05)^{2}\right.}$ \\
$\mathrm{n}=\mathbf{3 9 9}$
\end{tabular}

\section{Hubungan Antar Variabel}

\section{Hubungan privasi terhadap penggunaan fintech di kalangan masyarakat.}

Menurut UU ITE 2016 Penyidikan di bidang Teknologi Informasi dan Transaksi Elektronik sebagaimana dimaksud pada ayat (1) dilakukan dengan memperhatikan perlindungan terhadap privasi, kerahasiaan, kelancaran layanan publik, dan integritas atau keutuhan data sesuai dengan ketentuan peraturan perundang- undangan. Perlindungan privasi dikembangkan untuk mengatur perilaku orang lain yang dapat mengganggu dengan berbagai cara pada kehidupan seseorang.

Privasi dalam konteks ini dapat dipahami secara umum, membatasi kemampuan orang lain untuk mendapatkan, menyebarkan, atau menggunakan informasi tentang data diri (Anggara,2015). Jika dalam menggunakan fintech dalam bertransaksi online perlindungan privasi dapat terjamin, maka akan muncul keinginan untuk menggunakan fintech sebagai jasa pembayaran dalam bertransaksi.

Hal ini sesuai dengan penelitian yang dilakukan oleh Ika Suwanti (2017) bahwa privasi berpengaruh positif dan signifikan terhadap penggunaan internet banking BRI Purworejo(fintech), namun hal ini tidak sesuai dengan penelitian yang dilakukan oleh Aulia Wulan Dari (2018) bahwa tidak berpengaruh signifikan terhadap kegunaan layanan GoPay (Fintech).

\section{Hubungan keamanan terhadap penggunaan fintech di kalangan masyarakat}

Membuka transaksi bisnis melalui internet bukan berarti terhindar dari kejahatan oleh pihak lain sebagaimana bertransaksi secara konvensional. Potensi kejahatan berupa penipuan, pembajakan kartu kredit (carding) dan sejenisnya sangatlah besar 
apabila sistem keamanan (security) infrastruktur rendah. Maka dari itu dengan adanya penerapan Fintech pembayaran akan dirasa lebih aman. Menurut Ide Ismaili (2015) Persyaratan keamanan e-payment dalam transaksi online yaitu :

a. Kerahasiaan ( Confidentiality)

Kerahasiaan disini dimaksudkan adalah suatu data atau paket data tidak diperbolehkan dibaca atau diketahui oleh orang lain atau pihak lain yang tidak berkepentingan.

b. Otensitas ( Authenticity)

Otentisitas merupakan proses verifikasi terhadap identitas pengirim data

c. Integritas ( Integrity)

Keutuhan data atau paket data yang dikirim kan oleh pengirim dan penerima data atau paket data yang diterimanya benar- benar utuh dan tidak dimanipulasi atau diubah.

d. Tidak Dapat Disangkal (non repudiation)

Setiap pengiriman data atau paket data, pengirim tidak bisa menyangkal bahwa tidak pernah mengirim data atau paket data tersebut. Oleh karena itu dibutukan jaminan keamanan. Jaminan keamanan berperan penting dalam pembentukan kepercayaan dengan mengurangi perhatian konsumen tentang penyalahgunaan data pribadi dan transaksi data.

Ketika jaminan keamanan diperoleh dan sesuai dengan apa yang diharapkan oleh konsumen, maka akan menimbulkan keinginan untuk menggunakan fintech sebagai alat pembayaran . Hal ini sesuai dengan penelitian yang dilakukan oleh Ika Suwanti (2017) bahwa keamanan berpengaruh positif dan signifikan terhadap layanan internet banking BRI Purworejo( Fintech). Namun tidak sesuai dengan penelitian yang dilakukan oleh Aulia Wulan Dari (2018) bahwa tidak berpengaruh signifikan terhadap kegunaan pada layanan GoPay (Fintech).

\section{Kepercayaan terhadap penggunaan fintech di kalangan masyarakat}

Menurut Chuang (2016) mengidentifikasikan tiga indikator dari kepercayaan (trust), yaitu:

a. Keyakinan pada Layanan

Dimensi ini berkaitan dengan kepercayaan seorang individu terhadap layanan teknologi informasi yang disediakan oleh sebuah perusahaan layanan teknologi informasi. Jika seorang individu percaya pada perusahaan layanan teknologi informasi yang menyediakan layanan tersebut maka keyakinan individu dalam menggunakan layanan teknologi informasi tersebut menjadi semakin besar.

b. Persepsi Kualitas Layanan

Dimensi ini berkaitan dengan kepercayaan seorang individu terhadap kualitas sebuah layanan teknologi informasi. Sebuah layanan teknologi informasi 
menyediakan kualitas pengoperasian layanan yang berbeda. Jika seorang individu merasa terpenuhi atas kualitas transaksi sebuah layanan teknologi informasi maka kepercayaan seorang individu dalam menggunakan layanan teknologi informasi tersebut menjadi semakin besar.

c. Persepsi Keamanan Layanan

Dimensi ini berkaitan dengan kepercayaan seorang individu terhadap keamanan sebuah layanan teknologi informasi. Keamanan sebuah layanan teknologi informasi dapat dilihat pada kerahasiaan data dan kegiatan yang berlangsung selama mengoperasikan layanan tersebut. Jika seorang individu merasa terpenuhi atas keamanan transaksi maka kepercayaan seorang individu dalam menggunakan layanan teknologi informasi tersebut menjadi semakin besar.

Hal ini sesuai dengan penelitian yang dilakukan oleh Suyanto,dkk (2019) bahwa faktor-faktor kepercayaan seperti Kemampuan Menggunakan Komputer (CSE), Persepsi Kemudahan Persepsi Kegunaan Penggunaan (PEU),Sikap dan Minat Berpengaruh Positif terhadap Persepsi Kegunaan (POU) pada Perangkat Lunak Fintech. Namun hal ini tidak sesuai dengan hasil penelitian yang dilakukan oleh Veronica Yuniarti (2019) bahwa kepercayaan tidak berpengaruh terhadap penggunaan Fintech.

\section{Hubungan pengalaman terhadap penggunaan fintech di kalangan masyarakat}

Kurangnya pengalaman terhadap penggunaan dan manfaat fintech menjadikan layanan ini belum digunakan secara maksimal. Oleh karena itu, hal ini menunjukkan bahwa salah satu persepsi masyarakat berkaitan dengan harapan menyatakan perlunya sosialisasi lebih mendalam kepada para masyarakat agar semua lapisan masyarakat dapat mengetahui dan memanfaatkan layanan tersebut. Ketika seseorang memiliki pengetahuan yang kurang sebelumnya pada masalah yang dihadapi, pilihan perilaku yang akan dilakukan sebagian besar bergantung pada nilai harapan Assauri (2015).

Selain itu hal yang perlu diperhatikan oleh para penyelenggara fintech ialah kemudahaan atau kepraktisan dalam menggunakan layanan, sehingga masyarakat yang kurang memahami teknologi dapat menggunakannya dengan mudah sehingga diharapkan kedepannya akan mendapatkan pengalaman yag memuaskan.

Pengalaman yang memuaskan akan mengakibatkan keinginan untuk menggunakannya ulang di masa yang akan datang. Hal ini sesuai dengan penelitian yang dilakukan oleh Piquita Fadilla Bagasworo,dkk (2019) bahwa pengalaman berpengaruh terhadap penggunaan Fintech. Namun hal ini tidak sesuai dengan hasil penelitian yang dilakukan oleh Mustofa Abdul Karim (2018) bahwa pengalaman tidak berpengaruh terhadap penggunaan Fintech. 


\section{Hipotesis}

Ha1: Privasi berpengaruh terhadap penggunaan fintech dikalangan masyarakat

Ho1: Privasi tidak berpengaruh terhadap penggunaan fintech dikalangan masyarakat

Ha2: Keamanan berpengaruh terhadap penggunaan fintech dikalangan masyarakat

Ho2: Keamanan tidak berpengaruh terhadap penggunaan fintech dikalangan masyarakat

Ha3: Kepercayaan berpengaruh terhadap penggunaan fintech dikalangan masyarakat

Ho3: Kepercayaan tidak berpengaruh terhadap penggunaan fintech dikalangan masyarakat

Ha4: Pengalaman berpengaruh terhadap penggunaan fintech dikalangan masyarakat

Ho4: Pengalaman tidak berpengaruh terhadap penggunaan fintech dikalangan masyarakat

\section{HASIL PENELITIAN DAN PEMBAHASAN}

Teknik pengumpulan data dengan menyebarkan kuisioner melalui google form, populasi penelitian adalah Mayarakat yang tercatat di Kecamatan Tigaraksa Kabupaten Tangerang. Sedangkan sampel penelitian ini adalah masyarakat yang menggunakan Fintech dalam bertransaksi. Responden yang mengisi kuisioner yang disebar melalui Google form mendapatkan hasil 478 responden, lebih banyak dari sample yang digunakan oleh peneliti. Hal tersebut dikarenakan terdapat kuisioner yang diisi berulang yaitu sebanyak 28 responden.

\section{Analisis Regresi Linier Berganda}

Analisis regresi linier berganda digunakan untuk mengetahui pengaruh secara bersamaan antara variabel independent (Privasi, Keamanan, Kepercayaan dan Pengalaman) terhadap variabel dependent (penggunaan financial technology dikalangan masyarakat).

Tabel.2

Hasil Uji Regresi Linear Berganda

\begin{tabular}{|c|c|c|c|c|c|}
\hline \multirow[b]{4}{*}{ Model } & \multicolumn{5}{|c|}{ Coefficients $^{\mathrm{a}}$} \\
\hline & \multirow{2}{*}{\multicolumn{2}{|c|}{$\begin{array}{c}\text { Unstandardized } \\
\text { Coefficients }\end{array}$}} & \multirow{3}{*}{$\begin{array}{r}\text { Standardized } \\
\text { Coefficients } \\
\text { Beta }\end{array}$} & \multirow[b]{3}{*}{$\mathrm{t}$} & \multirow[b]{3}{*}{ Sig. } \\
\hline & & & & & \\
\hline & $\mathrm{B}$ & Std. Error & & & \\
\hline $1 \quad$ (Constant) & 1.609 & .768 & & 2.094 & .038 \\
\hline
\end{tabular}

Jurnal Ilmiah Akuntansi dan Ekonomi Volume. 6 Nomor. 1, Februari 2021 Hal. 65 


\begin{tabular}{|lr|r|r|r|r|}
\hline Privasi & -.026 & .043 & -.040 & -.600 & .549 \\
\hline Keamanan & .091 & .061 & .108 & 1.491 & .138 \\
\hline Kepercayaan & .150 & .058 & .185 & 2.573 & .011 \\
\hline Pengalaman & .436 & .054 & .552 & 8.121 & .000 \\
\hline a. Dependent Variable: Penggunaan Fintech di Kalangan Masyarakat \\
\hline
\end{tabular}

Dari tabel diatas dapat diketahui model persamaan regresi linear berganda sebagai berikut :

$$
\mathrm{Y}=\mathrm{a}+\beta_{1} \mathrm{X}_{1}+\beta_{2} \mathrm{X}_{2}+\beta_{3} \mathrm{X}_{3}+\beta_{4} \mathrm{X}_{4} \mathrm{e}
$$

$$
\mathrm{Y}=1,609-0,026 \times 1+0,091 \times 2+0,150 \times 3+0,436 \times 4 \mathrm{e}
$$

Model tersebut dapat di interpretasikan sebagai berikut :

1. Nilai a (konstanta) pada hasil pengujian di atas adalah sebesar 1,609 yang berarti bahwa jika variabel independen (privasi, keamanan, kepercayaan, dan pengalaman) konstan, maka penggunaan Fintech di kalangan masyarakat akan mengalami kenaikan sebesar 1,609. Nilai konstanta sebesar 1,609 menunujukkan nilai murni dari variabel penggunaan fintech (dependen) tanpa di pengaruhi variabelindependen.

2. Koefisien regresi pengaruh privasi (X1) adalah sebesar -0,026 dimana angka ini menujukkan bahwa setiap penurunan variabel privasi sebesar satu satuan, maka akan meningkatkan sebesar -0,026. Koefisien bernilai negatif artinya tidak terdapat hubungan positif antara privasi.

3. Koefisien Keamanan (X2) sebesar 0,091 artinya jika kepercayaan mengalami kenaikan 1 (satu) satuan, maka akan menaikkan penggunaan fintech di kalangan masyarakat sebesar 0,091 atau 9,1\%.

4. Koefisien Kepercayaan (X3) sebesar 0,150 artinya jika kepercayaan mengalami kenaikan 1 (satu) satuan, maka akan menaikkan penggunaan fintech di kalangan masyarakat sebesar 0,150 atau $15 \%$.

5. Koefisien Pengalaman (X4) sebesar 0,436 artinya jika pengalaman mengalami kenaikan 1 (satu) satuan, maka akan menaikkan penggunaan fintech di kalangan masyarakat sebesar 0,436 atau 43,6\%. 


\section{Uji Parsial (Uji t)}

\section{Tabel.3}

Hasil Uji t

\begin{tabular}{|c|c|c|c|c|c|}
\hline \multirow[b]{3}{*}{ Model } & \multicolumn{5}{|c|}{ Coefficients $^{\mathbf{a}}$} \\
\hline & \multicolumn{2}{|c|}{$\begin{array}{c}\text { Unstandardized } \\
\text { Coefficients }\end{array}$} & \multirow{2}{*}{$\begin{array}{c}\text { Standardized } \\
\text { Coefficients } \\
\text { Beta }\end{array}$} & \multirow[b]{2}{*}{$\mathrm{t}$} & \multirow[b]{2}{*}{ Sig. } \\
\hline & $\mathrm{B}$ & Std. Error & & & \\
\hline (Constant) & 1.609 & .768 & & 2.094 & .038 \\
\hline Privasi & -.026 & .043 & -.040 & -.600 & .549 \\
\hline Keamanan & .091 & .061 & .108 & 1.491 & .138 \\
\hline Kepercayaan & .150 & .058 & .185 & 2.573 & .011 \\
\hline Pengalaman & .436 & .054 & .552 & 8.121 & .000 \\
\hline
\end{tabular}

Berdasarkan Tabel di atas, maka dapat dijelaskan mengenai pengaruh secara parsial masing-masing variabel bebas sebagai berikut:

\section{Pengaruh Privasi (X1) terhadap Penggunaan fintech dikalangan Masyarakat} (Y)

Berdasarkan tabel diatas terlihat bahwa hitung $<\mathrm{t}_{\text {tabel }}$ yaitu $-0,600<1,972$ dan berdasarkan nilai signifikansi bahwa nilai signifikansi $0,549 \geq 0,05$. Hal ini berarti menunjukkan bahwa keputusan yang diambil adalah menerima $\mathrm{H}_{0}$ dan menolak $\mathrm{H}_{\mathrm{a}}$, berarti secara parsial privasi tidak berpengaruh signifikan terhadap penggunaan fintech di kalangan Masyarakat.

\section{Pengaruh Keamanan (X2) terhadap Penggunaan fintech dikalangan} Masyarakat (Y)

Berdasarkan tabel diatas terlihat bahwa hitung $<\mathrm{t}_{\text {tabel }}$ yaitu 1,491 $<1,972$ dan berdasarkan nilai signifikansi bahwa nilai signifikansi $0,138 \geq 0,05$. Hal ini berarti menunjukkan bahwa keputusan yang diambil adalah menerima $\mathrm{H}_{0}$ dan menolak $\mathrm{H}_{\mathrm{a}}$, berarti secara parsial keamanan tidak berpengaruh signifikan terhadap penggunaan fintech di kalangan Masyarakat.

\section{Pengaruh Kepercayaan (X3) terhadap Penggunaan fintech dikalangan Masyarakat (Y)}

Berdasarkan tabel diatas terlihat bahwa hitung $>\mathrm{t}_{\text {tabel }}$ yaitu 2,573>1,972 dan berdasarkan nilai signifikansi bahwa nilai signifikansi $0,011<0,05$. Hal ini berarti 
menunjukkan bahwa keputusan yang diambil adalah menerima $\mathrm{H}_{\mathrm{a}}$ dan menolak $\mathrm{H}_{\mathrm{o}}$, berarti secara parsial kepercayaan berpengaruh signifikan terhadap penggunaan fintech di kalangan Masyarakat.

\section{Pengaruh Pengalaman (X4) terhadap Penggunaan fintech dikalanganMasyarakat} (Y)

Berdasarkan tabel 4.29 diatas terlihat bahwa hitung > t tabel yaitu 8,121>1,972 dan berdasarkan nilai signifikansi bahwa nilai signifikansi $0,00<0,05$. Hal ini berarti menunjukkan bahwa keputusan yang diambil adalah menerima $\mathrm{Ha}$ dan menolak $\mathrm{H}_{\mathrm{o}}$, berarti secara parsial pengalaman berpengaruh signifikan terhadap penggunaan fintech di kalangan Masyarakat.

\section{Koefesien Determinasi $\left(R^{2}\right)$}

Uji Koefisien Determinasi (Uji R2 ) bertujuan untuk mengukur sejauh mana variabel bebas dapat menjelaskan variabel-variabel terikat, baik secara parsial maupun simultan. Nilai koefisien determinasi ini adalah antara nol sampai dengan satu $(0<\mathrm{R} 2<1)$.

Tabel.4

Hasil Uji Koefisien Determinasi (R2)

\begin{tabular}{|c|c|c|c|c|}
\hline \multirow[b]{2}{*}{ Model } & \multirow[b]{2}{*}{$\mathrm{R}$} & \multicolumn{3}{|c|}{ Model Summary } \\
\hline & & R Square & $\begin{array}{c}\text { Adjusted R } \\
\text { Square }\end{array}$ & $\begin{array}{l}\text { Std. Error of the } \\
\text { Estimate }\end{array}$ \\
\hline 1 & $.740^{\mathrm{a}}$ & .548 & .538 & 1.285 \\
\hline
\end{tabular}

Berdasarkan tabel di atas, diperoleh bahwa R Square sebesar 0,548 berarti hubungan keeratan secara bersama - sama antara variabel dependen dan variabel independen cukup kuat karena R lebih besar dari 0,5. Sedangkan nilai Adjusted R Square adalah sebesar 0,538. Ini menunjukkan bahwa sebesar 53,8\% variabel privasi, keamanan, kepercayaan dan pengalaman secara simultan memiliki pengaruh yang cukup terhadap penggunaan fintech dikalangan Masyarakat. Sedangkan sebagian sebesar 46,2\% dapat dipengaruhi oleh variabel-variabel lain yang tidak termasuk dalam penelitian ini. Variabel lain yang tidak masuk kedalam penelitian ini misalnya variabel kemudahan, kenyamanan, persepsi resiko.

\section{INTERPRESTASI HASIL PENELITIAN}

\section{Privasi $\left(X_{1}\right)$ tidak berpengaruh terhadap Penggunaan Finetch di Kalangan Masyarakat (Y)}

Jurnal Ilmiah Akuntansi dan Ekonomi Volume. 6 Nomor. 1, Februari 2021 Hal. 68 
Berdasarkan uji statistik diatas menunjukan bahwa privasi memiliki nilai thitung terlihat bahwa hitung $<\mathrm{t}_{\text {tabel }}$ yaitu $-0,600<1,972$ dan berdasarkan nilai signifikansi bahwa nilai signifikansi $0,549 \geq 0,05$. Hal ini berarti menunjukkan bahwa keputusan yang diambil adalah menerima $\mathrm{H}_{0}$ dan menolak $\mathrm{H}_{a}$, berarti secara parsial privasi tidak berpengaruh signifikan terhadap penggunaan fintech di kalangan Masyarakat.

Saat ini sudah ada UU ITE 2016 Penyidikan di bidang Teknologi Informasi dan Transaksi Elektronik sebagaimana dimaksud pada ayat (1) dilakukan dengan memperhatikan perlindungan terhadap privasi, kerahasiaan, kelancaran layanan publik, dan integritas atau keutuhan data sesuai dengan ketentuan peraturan perundangundangan. Hal ini menimbulkan adanya rasa aman dan berkurangnya rasa khawatir terhadap informasi pribadi atau data privasi yang diberikan, serta adanya kebutuhan penggunaan fintech dalam kehidupan sehari-hari. Sehingga data pribadi atau privasi mereka, bukanlah penentu mereka menggunakan fintech.

Hasil penelitian ini sejalan dengan penelitian sesuai dengan penelitian terdahulu yang dilakukan oleh Aulia Wulandari (2018) privasi tidak berpengaruh signifikan terhadap kegunaan fintech. Namun tidak sejalan dengan penelitian yang di lakukan oleh Ika Suwanti (2017) bahwa privasi berpengaruh positif dan signifikan terhadap penggunaan internet banking BRI Purworejo (fintech).

\section{Keamanan $\left(X_{2}\right)$ tidak berpengaruh terhadap Penggunaan Finetch di} Kalangan Masyarakat (Y)

Berdasarkan uji statistik diatas menunjukan bahwa $\mathrm{t}_{\text {hitung }}<\mathrm{t}_{\text {tabel }}$ yaitu $1,491<$ 1,972 dan berdasarkan nilai value signifikansi bahwa nilai signifikansi $0,138 \geq 0,05$. Hal ini berarti menunjukkan bahwa keputusan yang diambil adalah menerima $\mathrm{H}_{0}$ dan menolak $\mathrm{H}_{\mathrm{a}}$, berarti secara parsial keamanan tidak berpengaruh signifikan terhadap penggunaan fintech di kalangan Masyarakat.

Keamanan tidak menjadi penentu dalam penggunaan fintech. Selain sudah terdaftar dan diawasi OJK (Otoritas Jasa Keuangan), fintech ini telah diproteksi dengan sistem keamanan SSL 256 bit dan three layer security (password, secure PIN,dan kode OTP). Sistem keamanan lapis tiga ini ternyata selangkah lebih maju dari dunia perbankan yang hanya menggunakan 2 faktor Authentication (2FA) yaitu level password dan level OTP. Lapis keamanan ini mampu mengantisipasi malware seperti key-logger. Sementara itu, level OTP sendiri berupa password acak dan unik yang dikirimkan melalui SMS kepada pengguna dengan masa berlaku 3 menit. Dengan sistem keamanan lapis tiga ini data pribadi nasabah aman dan terlindungi dari ancaman hacker saat menggunakan fintech.

Dengan demikian maka responden dalam penelitian ini menyatakan bahwafaktor keamanan dalam transaksi online tidak perlu dipermasalahkan karena sistem fintech telah melakukan antisipasi terhadap semua hal-hal yang akan terjadi. Seperti keamanan dari virus yang masuk ataupun modus penipuan yang akan dilakukan pihak-pihak yang tidak bertanggung jawab (hacker). 
Hasil penelitian ini sejalan dengan penelitian terdahulu yang dilakukan oleh Aulia Wulandari (2018) kemanan tidak berpengaruh signifikan terhadap kegunaan fintech. Namun tidak sesuai dengan penelitian yang dilakukan oleh Ika Suwanti (2017) bahwa keamanan berpengaruh positif dan signifikan terhadap layanan internet banking BRI Purworejo( Fintech).

\section{Kepercayaan $\left(X_{3}\right)$ berpengaruh terhadap Penggunaan Finetch di Kalangan Masyarakat (Y)}

Berdasarkan uji statistic diatas terlihat bahwa $t_{\text {hitung }}>t_{\text {tabel }}$ yaitu 2,573 $>1,972$ dan dan berdasarkan nilai signifikansi bahwa nilai signifikansi $0,011<0,05$. Hal ini berarti menunjukkan bahwa keputusan yang diambil adalah menerima $\mathrm{H}_{\mathrm{a}}$ dan menolak $\mathrm{H}_{\mathrm{o}}$, berarti secara parsial kepercayaan berpengaruh signifikan terhadap penggunaan fintech di kalangan Masyarakat.

Hal ini membuktikan bahwa kepercayaan sangat dibutuhkan dalam penggunaan fintech, karena dalam melakukan pembayaran secara online kita merasa khawatir pembayaran kita berhasil atau tidak, data yang kita berikan tidak di sebarkan ke pihak lain atau tidak. Ketika kita sudah percaya dengan fintech yang kita gunakan, maka tidak akan muncul lagi kekhawatiran tersebut. Maka dapat disimpulkan bahwa kepercayaan harus diprioritaskan dalam mengunakan fintech.

Hasil penelitian ini sejalan dengan penelitian terdahulu yang dilakukan oleh Suyanto dkk (2019) kepercayaan berpengaruh signifikan terhadap kegunaan fintech. Namun tidak sejalan dengan penelitian yang di lakukan oleh Veronica Yuniarti (2019) bahwa kepercayaan tidak berpengaruh terhadap penggunaan Fintech.

\section{Pengalaman $\left(\mathrm{X}_{4}\right)$ berpengaruh terhadap Penggunaan Finetch di Kalangan Masyarakat (Y)}

Berdasarkan uji statistik diatas menunjukan bahwa hitung $>\mathrm{t}_{\text {tabel }}$ yaitu $8,121>$ 1,972 dan berdasarkan nilai signifikansi bahwa nilai signifikansi $0,00<0,05$. Hal ini berarti menunjukkan bahwa keputusan yang diambil adalah menerima $\mathrm{H}_{\mathrm{a}}$ dan menolak $\mathrm{H}_{\mathrm{o}}$, berarti secara parsial pengalaman berpengaruh signifikan terhadap penggunaan fintech di kalangan Masyarakat. Hal ini sesuai dengan teori TAM bahwa peranan pengalaman mempengaruhi seseorang untuk menggunakan fintech, dikarenakan adanya pengetahuan tertentu. Dimana pengetahuan ini diperoleh dari pengalaman. Sedangkan pengalaman diperoleh dari adanya kemudahan, kepuasan dan penerimaan suatu teknologi yang digunakan.

Hasil penelitian ini sejalan dengan penelitian yang dilakukan oleh Piquita Fadilla Bagasworo dan Ama Suyanto (2019) bahwa semakin banyak pengalaman konsumen terhadap penggunaan fintech, semakin memuaskan mereka denga pengalaman transaksi online masa lalu. Namun tidak sejalan dengan penelitian yang di lakukan oleh Mustofa Abdul Karim (2018) bahwa pengalaman tidak berpengaruh terhadap penggunaan Fintech. 


\section{KESIMPULAN DAN SARAN}

\section{Kesimpulan}

Berdasarkan hasil penelitian ini mengenai tentang Privasi, Keamanan, Kepercyaan dan Pengalaman terhadap Penggunaan Fintech di Kalangan Masyarakat, maka dapat ditarik kesimpulan sebagai berikut:

1. Privasi tidak berpengaruh signifikan terhadap penggunaan fintech dikalangan Masyarakat.

2. Kemanan tidak berpengaruh signifikan terhadap penggunaan fintech dikalangan Masyarakat.

3. Kepercayaan berpengaruh signifikan terhadap penggunaan fintech dikalangan Masyarakat.

4. Pengalaman berpengaruh signifikan terhadap penggunaan fintech dikalangan Masyarakat.

\section{Saran}

Harapan peneliti pada penelitian selanjutnya yaitu dapat memperbaiki kekurangankekurangan dalam penelitian ini, diantaranya:

1. Sebaiknya jika menggunakan kuisioner online (google form) menggunakan sistem pengunci email agar responden hanya dapat mengisi kuisioner sekali, sehingga tidak terjadi double isi kuisioner.

2. Penelitian berikutnya menggunakan variabel yang lebih banyak untuk mengukur pokok permasalahan yang sama.

3. Pokok pembahasan yang dibahas lebih rinci lagi

4. Menggunakan alat uji yang lebih baik lagi agar menghasilkan data yang akurat

5. Penelitian ini dilakukan pada masa pandemik sehingga sample nya masih terbatas pada wilayah kecamatan saja, sehingga peneliti menyarankan Sampel penelitian berikutnya menggunakan sampel yang lebih luas lagi seperti di kalangan masyarakat Kabupaten Tangerang secara keseluruhan sehingga akan menggambarkan hasil yang lebih mendekati kondisi yang sebenarnya. 


\section{DAFTAR PUSTAKA}

Ahmadi dan Hermawan. 2013. E-Business \& E-Commerce. Yogyakarta: Andi.

Assauri, S., 2015. Manajemen Pemasaran, PT Raja Grafindo Persada: Jakarta.

Dewi, S. 2015. Aspek Data Privacy Menurut Hukum Internasional, Regional danNasional, PT Refika Aditama : Bandung.

Ghozali, Imam. 2016. Aplikasi Analisis Multivariete Dengan Program IBM SPSS23 (Edisi 8). Cetakan ke VIII. Semarang : Badan Penerbit Universitas Diponegoro.

Jogiyanto, 2007. Sistem Informasi Keperilakuan. Edisi Revisi. Yogyakarta: AndiOffset

Mulyadi.2016.Sistem Informasi Akuntansi, Jakarta, Salemba Empat. Poerwadarminta. 2006. Kamus Besar Bahasa Indonesia. Jakarta: Balai Pustaka.Sugiyono. 2016. Metode Penelitian Kuantitatif, Kualitatif dan $R \& D$. Bandung :PT Alfabet.

.... 2002. Kamus Besar Bahasa Indonesia (Edisi Ketiga). Jakarta: Balai Pustaka.

Anggara. 2015. Menyeimbangkan Hak: Tantangan Perlindungan Privasi dan Menjamin Akses Keterbukaan Informasi dan Data di Indonesia, Jakarta:Institute Criminal of Justice Reform.

Chuang, dkk. 2016. The Adoption of Fintech Service: TAM Perspective.

International Journal of Management and Administrative Science. Vol.3.ISSN : 2225-7225.

Davis,F.D. 1989. "Perceived Usefulness, Perceived Ease of Use, and User Acceptance of Information Technology". MIS Quarterly.Vol. 13 No. 5: pp319-339

Ismaili, dkk, 2015, A Secure Electronic Payment Protocol Design and Implementation, International Journal of Computer Science and Network Security, Vol.15, No.5.

Undang-Undang Republik Indonesia Nomor 19 Tahun 2016UUD 1945 Pasal 28 G ayat (1) Peraturan Otoritas Jasa Keuangan POJK No. 13 /POJK.02/2018 Peraturan Otoritas Jasa Keuangan (POJK) No 77/POJK.01/2016Peraturan Bank Indonesia Nomor 19/12/PBI/2017

https://www.bps.go.id/ https://wearesocial.com/ https://www.ojk.go.id/

Jurnal Ilmiah Akuntansi dan Ekonomi Volume. 6 Nomor. 1, Februari 2021 Hal. 72 